\title{
REPLY TO COMMENT
}

\section{Reply to Comment of Encinas et al. (2014) on: 'Evidence for an Early-Middle Miocene age of the Navidad Formation (central Chile): Paleontological, climatic and tectonic implications' of Gutiérrez et al. (2013, Andean Geology 40 (1): 66-78)}

\author{
Jacobus P. Le Roux ${ }^{1}$, Néstor M. Gutiérrez ${ }^{1}$, Luis F. Hinojosa ${ }^{2}$, Viviana Pedroza ${ }^{1}, J^{\prime}$ an Becerra ${ }^{1}$
}

\author{
Departamento de Geología, Facultad de Ciencias Físicas y Matemáticas, Universidad de Chile-Centro de Excelencia en Geotermia \\ de los Andes, Plaza Ercilla 803, Santiago, Chile. \\ jroux@cec.uchile.cl; gutierrezn@ug.uchile.cl; viviana.pedroza@ug.uchile.cl; juantkd@gmail.com \\ 2 Laboratorio de Paleoecología, Facultad de Ciencias-Instituto de Ecología y Biodiversidad (IEB), Universidad de Chile, Las Palmeras \\ 3425, Santiago, Chile. \\ lfhinojosa@uchile.cl
}

Debate in science is always good because it forces both parties to re-examine the available evidence, which can often be interpreted in more than one way. In this case, it seems as if we are at least getting a little bit closer in our interpretation of paleowater depths for the Navidad Formation, as Encinas et al. (2014) now 'suspect that some of the sandstone strata at Punta Perro are shallow-water deposits', and that 'the depositional environment for part of the Navidad Formation was at least a few hundred meters deeper than the maximum paleodepth of $300 \mathrm{~m}$ proposed by Le Roux et al. (2013)'. This seems to be a far cry from the 1,500 $\mathrm{m}$ minimum depth proposed by these authors (Finger et al., 2007, 2013). However, we still differ on several aspects where we consider their evidence not only as weak but contradictory to their own proposals.

\section{Age of the Navidad Formation}

We thought that the age for the Navidad Formation had finally been laid to rest, but it seems as if Encinas et al. (2014) still harbor some doubts. Why else would they question the reliability of younger radiometric dates derived from pumice clasts, if these concur with Sr-isotope dates for the same units? We never doubted the Sr date of $12.1 \pm 0.7$ Ma obtained by
Encinas (2006) on a specimen of Neogloboquadrina acostaensis, but now Encinas et al. (2014) accuse us of contradicting ourselves when we 'admit that Gutiérrez et al. (2013) did not mention the Sr date, because it was too old'. We never admitted anything of the sort, as our remark referred to Encinas (2006), not ourselves. This should have been clear from the context of our paragraph, which stated: 'The Sr date of $12.1 \pm 0.7$ obtained by Encinas (2006) on $N$. acostaensis was thus rejected because it is too old. However, now that Finger et al. (2013) have re-identified $N$. acostaensis as another species they would reject this age again because it is too young, seeing that they now consider all their samples to be from the Burdigalian (20.4-16.0 Ma)'.

Encinas et al. (2014), however, do contradict themselves when they say that "no geologist would give credit to a $\mathrm{Sr}$ or K-Ar Miocene date obtained from a sedimentary succession containing fossils of rudists in living position, ammonites, and plesiosaurs', because an immense number of observations indicate that those taxa went extinct in the Cretaceous-Paleogene boundary'. Nevertheless, they are prepared to accept that five foraminifer index species or their close look-alikes appeared millions of years below their FAD as established by 'many millions of specimens', disappeared at 
around $16 \mathrm{Ma}$, and then re-appeared again later on, contradicting one of the 'laws' of evolution. We could still accept that a species may become extinct and that a later species may look so similar to it that experts can hardly tell the difference, but it is statistically difficult to believe that it can happen to five species occurring together in the same succession. In any case, Encinas et al. (2014) continue to evade a direct question we levelled at them in our Reply (Le Roux et al., 2013): Why, if only two of the five foraminifer species were misidentified by them, can the other three occur below their FAD if it is absolutely impossible? We really hoped to receive an answer to this mystery, but it seems that it will not be forthcoming.

While we agree that no geologic dating method is immune to pitfalls, we still do not see why the 12.1 \pm 0.7 Ma obtained for the $N$. acostaensis specimen by Encinas (2006) should be regarded as aberrant. This sample was taken from a $100 \mathrm{~m}$ thick succession of pure siltstones in the Navidad Formation just east of Matanzas, where it is impossible to determine the stratigraphic context. However, if it belongs to the upper, finer unit of Gutiérrez et al. (2013), as we suspect (taking account of possible faults), it would coincide with an obtained $\mathrm{Ar} / \mathrm{Ar}$ date of $12 \mathrm{Ma}$. This would also suggest that $N$. acostaensis and its very similar ancestral species(?) formed a lineage zone from the Early Miocene up to $3.56 \mathrm{Ma}$, as $12.1 \mathrm{Ma}$ is not that distant from its original FAD of $10.9 \mathrm{Ma}$.

\section{Sedimentary environment of the Navidad Formation}

Encinas et al. (2014) now acknowledge that the Navidad Formation includes shallow-marine deposits, but this complicates their interpretation of the tectonic setting even further. If such shallow-water facies are present within the sandstone-dominated intervals, which they generally consider to represent deep-water turbidites, it means that sea-level oscillations of $1,500 \mathrm{~m}$ plus are reflected within the latter. If it was difficult to imagine that the Navidad Formation as a whole represents tectonic subsidence of this magnitude caused by subduction erosion, it seems even more implausible that sea-level changes on this scale occurred during the deposition of a single sandstone package. On the other hand, if some sandstone packages are shallow-water deposits while others represent middle continental slope deposits, we have never been told what the differences are between them.

The presence of abundant, delicate leaf fossils in the Navidad Formation is now ascribed by Encinas et al. (2014) to E-type turbidity currents, because classic I-type turbidity currents 'have an overall tendency to lose lighter plant materials that stay suspended and get left behind by the main flow'. E-type turbidity currents originate from hyperpycnal flows, and according to Zavala et al. (2006) 'a single hyperpycnal discharge could not travel faster than its related leading head. Because the leading head is characterized by accumulation under traction-plusfallout conditions, flow velocities are in the order of few centimeters per second.' In fact, it can be calculated that the velocity of a $1 \mathrm{~m}$ thick flow over the continental shelf with a slope of $0.1^{\circ}$ would be less than $50 \mathrm{~cm} \mathrm{~s}^{-1}$ (Appendix 1). A calculation of the current velocity required to transport an articulated bivalve of $3 \times 2 \times 0.7 \mathrm{~cm}$ with a mean density of $2 \mathrm{~g} \mathrm{~cm}^{3}$ (assuming that it is still alive) yields about $150 \mathrm{~cm} \mathrm{~s}^{-1}$ (Appendix 2). Such currents may thus be able to transport leaves, but definitely not even small molluscs, ruling this out as a mechanism for their reworking over the shelf into deeper water. The occurrence of barnacles and other rocky shoreline species in deep-water turbidites off the Canary Islands (which have a steep offshore bottom slope) would therefore require normal turbidity currents or other mass flow processes, so that they cannot be used as a proxy for Navidad if E-type turbidity currents are invoked.

We agree that hyperpycnal flows could have been responsible for depositing some of the sandstones at Navidad, but such flows do not necessarily take place in deep water. They are in fact quite common at the mouths of most contemporaneous rivers (Mulder and Syvitski, 1995; Kineke et al., 2000; Johnson et al., 2001; Mulder et al., 2001, 2003) and pass downslope into normal turbidity currents at depths of a few tens of meters (Lamb and Mohrig, 2009), which would concur with our interpretation of most of the Navidad sandstones as shallow water sediments deposited in the vicinity of river mouths and possibly deltas. The shallow water molluses recorded within them could therefore be attributed to their in situ occurrence, without having to explain the contradiction of their association with leaf accumulations.

The occurrence of gigantic granitic boulders above a siltstone succession was attributed by 
Finger et al. (2013) and now again by Encinas et al. (2014) to shelf-margin failure and downslope transport by mass movements. Furthermore, they propose that large rip-up clasts in the associated breccia were dislodged by the granitic boulders as they moved downslope. Although the exact location of these boulders was not clear from their original description, according to their figure 3 they are very similar to those found $1.2 \mathrm{~km}$ to the southwest. In the latter case, Encinas (2006) and Encinas et al. (2014) accept that they form part of a 'basal conglomerate', which is typically deposited during marine transgression over a sub-aerially eroded batholith. Nevertheless, the boulders at the northern end of the peninsula, also exposed at sea level, are interpreted by them as olistoliths occurring on the continental slope, in spite of the fact that the strata at Punta Perro are practically horizontal and underlie the same sandstone package. Are we then to believe that there is a lateral, northeastward facies change from coastal to continental slope deposits over a distance of $1.2 \mathrm{~km}$ ?

At both localities, most of the boulders are well rounded and even polished, and as we pointed out in our original Reply, there is no known process that can round and polish such boulders at the edge of the continental shelf. This can only be done by waves or during transport over a considerable distance by a turbulent current. Rounding of clasts cannot take place within a hyperconcentrated debris flow. We also pointed out that boulders of this basal conglomerate are often associated with barnacle fragments (Encinas, 2006), which indicate that they were derived from coastal areas. Moreover, outcrops of a very similar granitic rock occur not far from Punta Perro northeast of the Rapel River mouth, while some of the measured sections (e.g., MEMB, CANEL, PTOR) in Encinas (2006) depict them as directly overlying granite. It is therefore far more logical to assume that the boulders at the northern end of the Punta Perro Peninsula were derived from wave erosion of a nearby coastal cliff composed of granitic rocks, from which point they may have been transported for a short distance offshore. The fact that they are associated with a mega-breccia composed of substrate rip-up clasts suggests that the transport mechanism could have been a tsunami backflow (Le Roux and Vargas, 2005). Paris et al. (2010), for example, documented that the Indian Ocean tsunami of 2004 transported large boulders about $2 \mathrm{~km}$ offshore.
Lastly, we do not believe that the boulders could have dislodged the rip-up clasts as they moved downslope. To rip a block from the substrate, rolling certainly would not do the trick, and it is difficult to envisage these huge boulders bouncing along in any flow. On the other hand, mega-breccias with large rip-up clasts are known at various localities along the Chilean coastline where they are not associated with basement boulders (e.g., Le Roux et al., 2004, 2008).

Encinas et al. (2014) accept that 'some of the Navidad Formation may be of deltaic origin', with which we concur. In fact, we never stated that all the sandstones were deposited in this environment either, but based this interpretation partly on the seismic profile showing a coarsening-upward succession from siltstone-dominated to sandstone-dominated deposits. It is significant that the scale and slopes (about $2^{\circ}$ ) of the observed clinoforms in the siltstone package match, for example, those of Johannessen and Steel (2005; fig. 2) for shelf deltas. As concerns the interpreted profile, the first author (JPLR) received the original figure in the form that it was published in Le Roux et al. (2013), and did not realize that the lower 'sandstone-siltstone packages' were reflection artefacts of the upper two packages. Figure 4 of Encinas et al. (2014) shows that this may indeed be the case, and JPLR accepts full responsibility for the original misinterpretation. It seems that BeicipFranlap (1996) made the same mistake by identifying three marine sequences in another profile in the same area. Although the full profile, including the section published by Contardo et al. (2008), was received, only the area including the present continental slope was chosen, without realizing that this part of the profile was not originally published by the latter authors. Nevertheless, we wish to clarify some aspects and respond to the comments by Encinas et al. (2014) on this interpretation. First, they do not understand how the different lithologies in the seismograph were identified. Sandstone-dominated intervals measured in the Navidad Formation are typically of the order of 30-40 m, as shown in measured profiles (e.g., PPW2) of Encinas (2006). These are commonly separated from similar sandstone-dominated units by $10-20 \mathrm{~m}$ thick siltstone-dominated sections. We consider such a combination of two thicker, sand-dominated sub-units with a middle silt-dominated sub-unit, to represent a 'sandstone-dominated package', which would have a total thickness of about 70-100 $\mathrm{m}$ in 
the on-land section of the Navidad Formation. On the other hand, the only good sections of the upper part of the Navidad Formation are represented in column PAR and possibly column Nav\#5 of Encinas (2006), in which siltstone-dominated intervals of 80-100 $\mathrm{m}$ are shown. This is what we would consider to be a 'siltstone/shale-dominated package'. Figure 4 of Encinas et al. (2014) indicates that the upper, horizontally stratified seismic unit is composed of parallel, continuous reflectors, with a total thickness of about $50 \mathrm{~m}$. However, we assumed that there would be a seaward decrease in the proportion of coarser sediments, so that the sandstone packages would be thinner than those measured on-land. For this reason we identified the $\sim 50 \mathrm{~m}$ thick, horizontal unit as a sandstone package and the at least $85 \mathrm{~m}$ thick unit with inclined reflectors and reflection-free zones as a siltstone package. Encinas et al. (2014) calculated a thickness of 100-300 $\mathrm{m}$ for these siltstone packages, but obviously made a mistake with the scale. There is thus no contradiction between our measured on-land thickness of $220 \mathrm{~m}$ and the seismic profile thickness of $135 \mathrm{~m}$ at the edge of the continental shelf. In any case, we wish to point out that figure 3 of Gutiérrez et al. (2013) is a composite profile of the Navidad Formation. Combining profiles PPW2 and PAR of Encinas (2006) gives a similar on-land thickness of $230 \mathrm{~m}$, although we suspect that the uppermost part of the last section might belong to the Licancheu Formation. Lastly, we do not understand their argument in pointing out that "no siltstone or sandstone interval in the Matanzas section exceeds $\sim 10$ m'. We suspect that they misunderstood the concept of a 'package' as meaning that it is composed of only one lithology, as reflected in the last paragraph of their discussion.

Examining figure 4 of Encinas et al. (2014), it can be seen that the reflectors of the sandstone package are much more inclined over the present continental slope than further to the east, where they are practically horizontal. This confirms to us that the latter section as well as the on-land portion of the Navidad Formation was deposited on the continental shelf, because otherwise the reflectors would have shown a similarly steep inclination.

At Matanzas, a section characterized by abundant leaf fossils, we are told that 'classic turbidites are overlain by a massive sandstone containing large floating intraclasts, shallow water molluscs, bathyal foraminifera, and psychrospheric ostracodes', which is used as evidence for deep-water deposition and reworking of shallow water fauna. However, if we require hyperpycnal flows to allow the accumulation of abundant leaves in a deep-water environment, they would neither be able to transport shallow water molluscs nor deposit 'classic turbidites'. According to Zavala et al. (2006), hyperpycnal deposits are characterized by fine-grained sandstones with climbing ripples and plane beds, or massive beds and low-angle cross stratification. This is very different from the typical fining-upward Bouma cycles of classic turbidites, which would have been deposited by I-type turbidity currents not allowing the accumulation of abundant leaf fragments.

Although the presence of articulated crabs and bivalves is not necessarily an indication of shallow marine deposition, there is no direct evidence that they were displaced downslope by turbidity currents either. Encinas et al. (2014) state that 'some of the rocky shoreline species, occur in conglomerate beds interbedded with turbidites and thin siltstone beds (e.g., section SBP in Encinas, 2006) indicating that the fossils were transported at least below fair-weather wave base and not near the coast.' We disagree with this interpretation, because the so-called turbidites in this section are shown as mostly massive, non-graded sandstones with occasional intraclasts, horizontal lamination, fluid escape structures, and convolute lamination. None of these features can be considered as diagnostic of deep-water I-type turbidites, although they might represent shallow water hyperpycnal flows as shown by the fact that they contain trace fossils mainly dominated by Thalassinoides. They also include some Ophiomorpha, Diplicraterion, Chondrites, Zoophycos, and Lophoctenium. With the exception of the last trace, which is made by bivalves and has been documented even on tidal flats (Poschmann and Braddy, 2010), Buatois et al. (2002) consider all of these traces to occur above the storm wave base. According to Nichols (1999) the latter generally lies at a depth of about $50 \mathrm{~m}$, with $200 \mathrm{~m}$ only being reached in extreme cases. Therefore, neither sedimentary structures nor trace fossils necessarily indicate water depths greater than $200 \mathrm{~m}$ or classic deep-water turbidity current activity. As we pointed out in our original Reply, the Navidad sandstone packages contain shallow water mollusc species, whereas the siltstone-shale packages host deeper water species (Nielsen et al., 2004). Sands deposited in deep water by turbidity currents should 
be colonized shortly thereafter by local, deep-water organisms, thus producing a mixture of shallow and deep-water species.

Every precaution was taken in the field and laboratory to avoid contamination by present-day pollen or insects, but it is not impossible that the insect wings and butterfly scales found in our samples might have such an origin. However, at least the insect head $(\sim 100 \mu)$ appears to be that of a Hymenoptera of very small size, possibly belonging to the family Trichogrammatidae or fairy wasps (Fig. 1). Trichogrammatidae have been found as fossils in amber from the Early Cretaceous to the Pleistocene (Schmidt et al., 2010; Fig. 4). Therefore, it cannot be ruled out that our specimens may be fossils.

As far as microfossils are concerned, the fact that most of the Neogene benthic foraminifera similar or identical to those from Navidad were recovered at a water depth of 3,212 m at ODP Site 1237, does not prove anything. If these species were recovered from deposits older than 2.6 Ma they have nothing to do with the present water depth, so that the latter cannot be used as a proxy to determine the depth range of these species. The same goes for the psychrospheric ostracodes. Furthermore, although there may be no direct evidence of upwelling in the Navidad Formation itself, there are phosphate and diatom beds in the time-equivalent Coquimbo Formation at Tongoy and Carrizalillo to the north (Le Roux et al., 2005b, 2006). The precipitation of phosphate or diatom beds requires a long period of upwelling during which clastic sediments are not supplied to the outer continental shelf, which would have been unlikely during Navidad deposition given the humid climate at the time (Hinojosa and Villagrán, 2005; Gutiérrez et al., 2013).

The scarcity of certain sedimentary structures such as trough, planar, herringbone and hummocky cross-bedding, as well as flaser bedding in the Navidad Formation, is used by Encinas et al. (2014) as an indication of deep water deposition. However, most of these structures are common only on tidal flats, the subtidal zone or the upper shoreface, i.e., depths less than about $20 \mathrm{~m}$, whereas most of the Navidad sandstones were probably deposited at somewhat greater depths. As most hyperpycnal flows occur in shallow water, the sedimentary structures typically associated with them can also not be used to infer a deep-water environment. Furthermore, two other factors could explain the relative scarcity of megaripple structures in the Navidad Formation. First, a large proportion of the sandstones are very fine, i.e., with grain-sizes between 0.0625 and $0.125 \mathrm{~mm}$. Megaripples simply do not develop in such fine sediments, even if the hydrodynamic conditions are favorable (Southard and Boguchwal, 1990). Second, it should not be forgotten that many macroscopically massive sandstones are in fact cross-laminated, but this is only revealed by X-ray treatment (Pszonka et al., 2013). As concerns wave ripple marks, they have well-defined characteristics such as rounded troughs and sharp, symmetrical, bifurcated crests, so it would be difficult to confuse them with current ripples. Nearer the shore such ripples can become
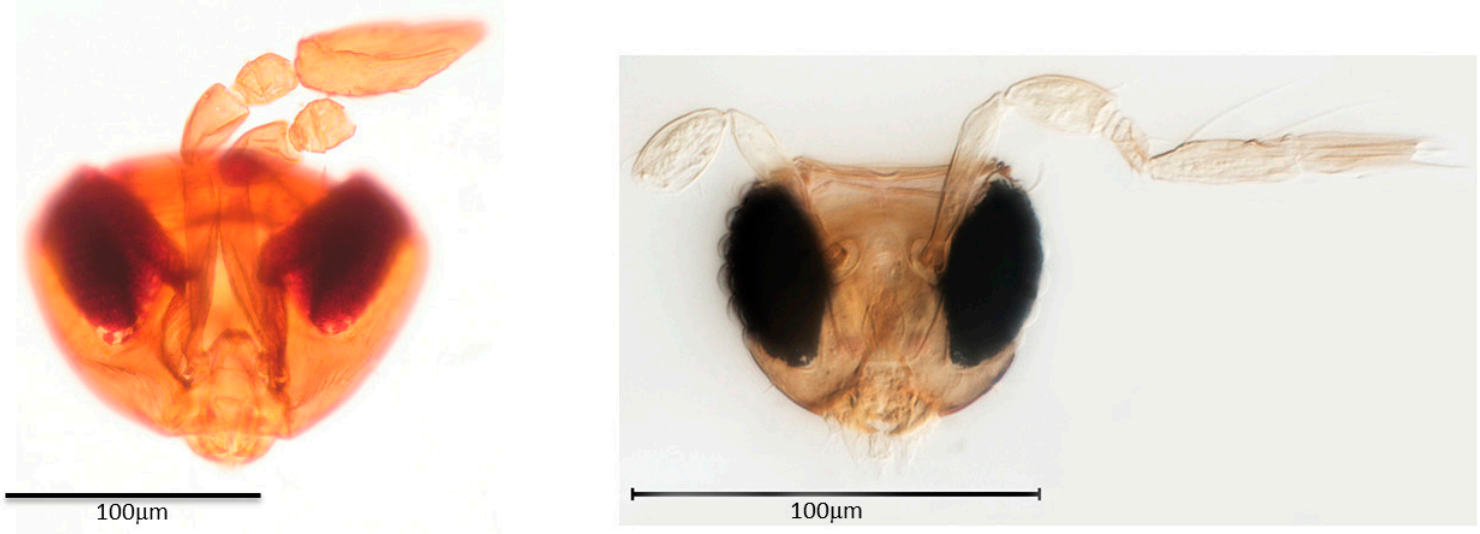

FIG. 1. Comparison of fairy wasp (Trichogrammatidae) heads to show similarity in scale and shape. Left: specimen from Navidad; right: Megaphragma sp. (Huber and Noyes, 2013). 
slightly asymmetrical, but they do not lose their basic form. Unfortunately, the outcrop at the eastern side of the Punta Perro Peninsula has deteriorated considerably over the last 14 years, but at least one of us (J.P. Le Roux) visited that outcrop when it was still in good condition and has no doubt that they are indeed wave ripples.

No-one denies that deep-water successions can be complex, but we were referring to turbidites, not submarine canyon deposits or mass flow complexes. The first author (J.P. Le Roux) has firsthand experience with Precambrian turbidites that are comparable to the descriptions of many similar deposits worldwide, and they are very different from the Navidad succession. Again, we wish to reiterate that water escape structures, sheared flames, thin siltstone partings, and floating clasts are not exclusive to turbidites, and that turbidites are not exclusive to deep water environments either. They can occur just as well on delta slopes. And when we referred to sandstone packages, we never stated that they were composed only of sandstone. The term 'package' refers to a unit dominated by a certain lithology, but a sandstone package can contain siltstone, conglomerate and coquina lenses, as for example observed at Punta Perro.

\section{Paleoseeps}

Encinas et al. (2014) confirm that paleoseeps can occur in shallow water, and distinguish between trophic web seeps based on photosynthesis, and deep-water seep communities relying on chemosynthesis. The latter type has $\delta^{13} \mathrm{C}$ isotopic signatures between $-40 \%$ and $-50 \%$, whereas the signature of shallow-water seeps lie between - $16 \%$ and-20\%o. For the Navidad paleoseep, Contardo and Mena (2012) reported mean $\delta^{13} \mathrm{C}$ values of $-40 \%$ and $-29.5 \%$. Therefore, these values indicate neither very shallow nor deep water, as they lie in-between the extremes mentioned above. More important, the presence of microbialites is also mentioned by Encinas et al. (2014). Most microbialites grow within the photic zone, although Turner et al. (2010) reported optimal growth in intermediate water depths between fair-weather wave base and an upper depth limit determined by light attenuation. The characteristics of paleoseeps in the Navidad Formation, therefore, more strongly support a shallow to intermediate water depth than deep water.

\section{Tectonosedimentary evolution and sequence stratigraphy of the Navidad Formation}

Encinas et al. (2014) quote us completely out of context when they maintain that, according to us, all siltstones represent deeper water environments and all sandstones shallower water. What we did propose is that thick siltstone-shale packages with clinoforms could represent delta slope deposits prograding onto the continental shelf. On the other hand, sandstone packages (which can include siltstone lenses formed by channel abandonment, for example) could reflect underwater delta platforms. We did not for one moment imply that such lithological changes within sandstone packages indicate abrupt water depth changes of around $200 \mathrm{~m}$, since they are most often caused by the lateral migration of sub-environments such as channels. Encinas et al. (2014) now find it 'hard to imagine' that abrupt water-depth shifts of the order of $200 \mathrm{~m}$ occurred, but strangely, by admitting that shallow water environments are also reflected within their so-called 'deep-water' sandstone packages, they have no trouble accepting abrupt water-depth changes of more than a thousand meters.

Seeing that the age of the Navidad Formation is now considered to be Early and not Late Miocene, Encinas et al. (2014) changed their subsidence model to one caused by roll-back of the subduction slab instead of subduction erosion. They propose that this occurred in south-central Chile between 25-24 Ma (after Muñoz et al., 2000). While concurring with plate roll-back, we do not agree on the duration of this event. Lavenu and Encinas (2005) in their study of brittle deformation in the Darwin Group (sensu Le Roux et al., 2013) concluded that extensional tectonism is manifested by synsedimentary faults in the Navidad, Licancheu and La Cueva Formations, which was interrupted by a period of compression during the Tortonian (Rapel Formation). The Navidad Formation also has compression-generated structures, although this could have been generated during the Rapel compressional stage. Considering the revised ages of these formations (Gutiérrez et al., 2013), extensional structures in the Darwin Group imply that roll-back in fact occurred from the Early Miocene up to the end of the Neogene. If it is accepted that uppermost continental slope sediments may be represented in the upper member of the Navidad Formation (Le Roux et al., 2013), roll-back would also explain the seaward shift of the 
continental margin, which presently occurs tens of kilometers to the west of its position at around $12 \mathrm{Ma}$. As suggested by Gutiérrez et al. (2013), the Navidad Formation reflects a deepening marine basin with a major transgression stage beginning at around $15 \mathrm{Ma}$, coinciding with the greatest depositional water depths recorded between 12-11 Ma in the Coquimbo Basin (Le Roux et al., 2005b), as well as a change from peat swamp conditions to deep marine embayments in the Valdivia and Osorno Basins (Le Roux and Elgueta, 2000; Elgueta et al., 2005). According to our tectono-sedimentary model, therefore, general basin subsidence and transgression during the Neogene were interrupted by periods of stable sea level, which perhaps coincided with compressional stages. The subsidence led to onlap of the Darwin Group onto the continent, reaching its maximum eastward extent at the end of La Cueva sedimentation shortly after $2.7 \pm 0.3 \mathrm{Ma}$ (radiometric date on pumice clasts; Encinas, 2006). Le Roux et al. (2005a) also concluded that subsidence in the Coquimbo Basin (interrupted by the arrival of an extension of the Juan Fernández Ridge) lasted until 2.4-2.1 Ma, when rapid uplift commenced.

In the Rapel area, Encinas et al. (2014) propose that "erosion of the Navidad Formation exposed the basement prior to the transgression that deposited the Licancheu Formation'. As we pointed out in our Reply (Le Roux et al., 2013), if the Navidad Formation had been deposited in a water depth of $1,500 \mathrm{~m}$, its paleo-coastline would have been many tens of kilometers to the east of the present coastline, and to sub-aerially erode all these deposits considerable uplift must be inferred around the SerravalianTortonian boundary. Therefore, one would expect the preserved Navidad deposits to be tilted sharply and that there would be a clear angular unconformity between the Navidad and Licancheu Formations, which is not the case. Instead, it has been described as a paraconformity (Encinas, 2006). In addition, a major angular unconformity is not observed between the equivalent Ranquil and Tubul Formations in the Arauco Basin (Becerra et al., 2013). Lastly, Licancheu sedimentation still took place during an extensional regime (Lavenu and Encinas, 2005), so that there would be no clear mechanism for rapid uplift at this time.

Lavenu and Encinas (2005) do record a compressional phase during deposition of the overlying Rapel Formation, which within a general plate roll-back setting can possibly be attributed to detachment of the deeper part of the subduction slab. Buiter et al. (2002), for example, showed that this process can lead to surface uplift of 2-6 km in the case of subduction with a non-migrating trench system, while this may be even higher for the case of roll-back preceding detachment. For example, Timor in the Southern Banda Arc experienced an uplift of around $5 \mathrm{~km}$ from Mid-Pliocene to recent, presumably related to detachment of the down-going Australian plate (Audley-Charles, 1986; Price and AudleyCharles, 1987). Considering that subduction-slab detachment is only a trigger to subsequent isostatic uplift and that the latter might be of much longer duration, the subduction effect of subsequent plate roll-back could be largely overridden. We therefore propose that slab detachment may have taken place at around $10 \mathrm{Ma}$ that greatly accelerated uplift of the Andes Range and temporarily reversed the plate roll-back, changing an extensional into a compressional regime. Gregory-Wodziki (2000) and Bissig et al. (2002) also concluded that important surface uplift involving several thousands of meters occurred during and after the Late Miocene. This was followed by renewed plate roll-back, of which the subduction effect was partly cancelled out by isostatic uplift resulting from the preceding detachment, and a second major detachment during the early Pleistocene.

Encinas et al. (2014) contend that, 'if the Navidad Basin had been filling during a widespread and continuous marine transgression, then the younger units would represent a progressive deepening sequence...' whereas ...'sedimentological evidence clearly indicates that (they) were deposited in shallow-marine settings'. Obviously, there is a misunderstanding of basic concepts here. If we consider what happens at a fixed point (say, at the present coastline), marine transgression would cause the water depth to increase at this locality. However, the paleo-coastline would progressively shift inland, and the younger deposits encountered east of our fixed point would represent these shallow-water coastal environments. In any case, we did not propose continuous marine transgression, but periods of rapid sea-level rise causing backstepping onto the continent, interspersed with sea-level stillstands that would allow delta and coastal progradation. This would explain the apparent clinoforms observed within the siltstone packages in the seismic profile. 


\section{Stratigraphy of the Navidad Basin}

Encinas et al. (2014) do not agree with Gutiérrez et al. (2013) that the on-land portion of the Navidad Formation can be divided into a coarser-grained lower unit and finer-grained upper unit. Nevertheless, the composite profile (Fig. 2) of Encinas (2006) shows an $85 \mathrm{~m}$ thick, clearly siltstone-dominated unit (lower part of section PAR) overlying a basal, sandstonedominated unit of similar thickness (section MAT). In the upper part of the PAR section, there is a second thick, sandstone-dominated unit above the siltstone package, which in turn is overlain by the Licancheu Formation. Gutiérrez et al. (2013) did not include the latter sandstone package in their measured section of the Navidad Formation, but we are not convinced that this portion does not belong to the Licancheu Formation, as the contact is described by Encinas et al. (2014) themselves as 'difficult to study because it is partially obscured by vegetation'. Under such circumstances, we find it strange that it was placed in the middle of an $85 \mathrm{~m}$ thick sandstone package and not at the base of the latter. In fact, if it turns out that his indicated limit between the Navidad and Licancheu Formations is not a paraconformity but a normal contact, it would make much more sense to shift this boundary to the top of the lower, sandstonedominated unit of Gutiérrez et al. (2013). In this way,

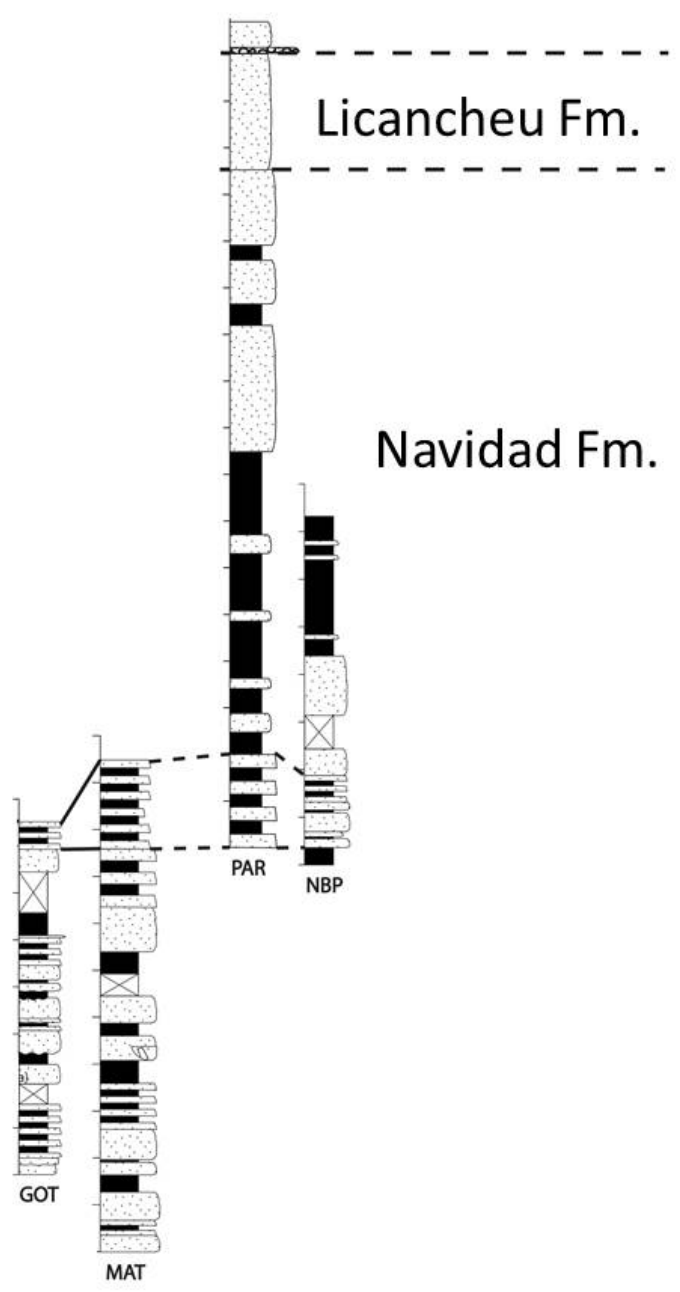

FIG. 2. Stratigraphic columns measured in Navidad Formation by Encinas (2006), showing a total combined thickness of $230 \mathrm{~m}$. Section MAT is a sandstone-dominated package, and the lower part of section PAR is a siltstone/shale dominated package. The whole sandstone-dominated upper part of section PAR might in fact belong to the Licancheu Formation. 
formations in the Darwin Group would be composed of coarsening-upward siltstone- to sandstone-dominated cycles reflecting delta and coastal progradation, while the contacts between them would be marked by major marine flooding surfaces.

\section{Acknowledgements}

J.P. Le Roux worked under the auspices of CONICYTFONDAP Project 15090013, 'Andean Geothermal Center of Excellence (CEGA)'. In the case of FH, this research was funded by Projects Fondecyt 1060041 and 1090339 , as well as the Millennium Institute of Ecology and Biodiversity (IEB), grant P05-002 from Mideplan, and PFB 23 from CONICYT. N.M. Gutiérrez is indebted to the Instituto Milenio de Ecología y Biodiversidad for a postgraduate grant. J. Becerra thanks E. Vera and FONDEF Project D00I1104 for releasing the seismic reflection data, as well as CONICYT for a post-graduate grant.

Finally, we wish to thank Andean Geology for allowing this debate, which helped us to clarify some concepts but also opened up new avenues for research.

\section{References}

Audley-Charles, M.G. 1986. Rates of Neogene and Quaternary tectonic movements in the Southern Banda Arc based on micropalaeontology. Journal of the Geological Society 143: 161-175. London.

Becerra, J.; Contreras-Reyes, E.; Arriagada, C. 2013. Structure and tectonics of the southern Arauco Basin, south-central Chile $\left(\sim 38^{\circ} \mathrm{S}\right)$. Tectonophysics 592: 53-66.

Beicip-Franlab. 1996. Petroleum exploration play types in the sub-andean basins. Beicip-Franlab 2: $136 \mathrm{p}$.

Bissig, T.; Clark, A.H.; Lee, J.K.W.; Hodgson, C.J. 2002. Miocene landscape evolution and geomorphologic controls on epithermal processes in the El Indio-Pascua $\mathrm{Au}-\mathrm{Ag}-\mathrm{Cu}$ Belt, Chile and Argentina. Economic Geology 97: 971-996.

Buatois, L.; Mángano, G.; Aceñolaza, F. 2002. Trazas Fósiles: Señales de Comportamiento en el Registro Estratigráfico. Museo Paleontológico Egidio Feruglio Chubut: $382 \mathrm{p}$.

Buiter, S.J.H.; Govers, R.; Wortel, M.J.R. 2002. Twodimensional simulations of surface deformation caused by slab detachment. Tectonophysics 354: 195-210.

Contardo, X.; Cembrano, J.; Jensen, A.; Díaz-Naveas, J. 2008. Tectono-sedimentary evolution of marine slope basins in the Chilean forearc $\left(33^{\circ} 30^{\prime}-36^{\circ} 50^{\prime} \mathrm{S}\right)$ : insights into their link with the subduction process. Tectonophysics 459 (1-4): 206-218.
Contardo, X.; Mena, E. 2012. Evidencias, caracterización e implicancias del primer seep fósil descubierto en la costa emergida de Chile central. In Congreso Geológico Chileno, No. 13, Actas: CD-Rom T5: 663-665. Antofagasta.

Elgueta, S.; McDonough, M.; Le Roux, J.P.; Urqueta, E.; Duhart, P. 2005. Estratigrafía y Sedimentología de las Cuencas Terciarias de la Región de Los Lagos (39-41³0’S). Servicio Nacional de Geología y Minería, Boletín 57: 50 p. Santiago.

Encinas, A. 2006. Estratigrafía y sedimentología de los depósitos marinos mio-pleistocénicos del área de

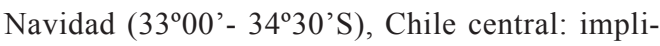
caciones con respecto a la tectónica del antearco. Ph.D. dissertation (Unpublished), Universidad de Chile: $177 \mathrm{p}$.

Encinas, A.; Finger, K.L.; Nielsen, S.N.; Contardo, X. 2014. Comment on Reply to Comment of Finger et al. (2013) on: 'Evidence for an Early-Middle Miocene age of the Navidad Formation (central Chile): Paleontological, paleoclimatic and tectonic implications'of Gutiérrez et al. (2013, Andean Geology 40 (1): 66-78). Andean Geology 41 (3): 635-656. doi: 10.5027/ andgeoV41n3-a07.

Finger, K.L.; Encinas, A.; Nielsen, S.N. 2013. Comment on 'Evidence for an Early-Middle Miocene age of the Navidad Formation (central Chile): Paleontological, paleoclimatic and tectonic implications' of Gutiérrez et al. (2013, Andean Geology 40 (1): 66-78). Andean Geology 40 (3): 570-578. doi: 10.5027/ andgeoV40n3-a10.

Finger, K.L.; Nielsen, S.N.; DeVries, T.J.; Encinas, A.; Peterson, D.E. 2007. Paleontologic evidence of sedimentary displacement in Neogene forearc basins of central Chile. Palaios 23: 3-16.

Gregory-Wodziki, K.M. 2000. Uplift history of the Central and Northern Andes: A review. Geological Society of America, Bulletin 112: 1091-1105.

Gutiérrez, N.; Hinojosa, L.F.; Le Roux, J.P.; Pedroza, V. 2013. Evidence for an Early-Middle Miocene age of the Navidad Formation (central Chile): paleontological, paleoclimatic and tectonic implications. Andean Geology 40 (1): 66-78. doi: 10.5027/andgeoV40n1-a03.

Hinojosa, L.F.; Villagrán, C. 2005. Did the South American Mixed Paleofloras evolve under thermal equability or in the absence of the Andes during the Tertiary? Palaeogeography, Palaeoclimatology, Palaeoecology 217: 1-23.

Huber, J.T.; Noyes, J.S. 2013. A new genus and species of fairyfly, Tinkerbella nana (Hymenoptera, Mymari- 
dae), with comments on its sister genus Kikiki, and discussion on small size limits in arthropods. Journal of Hymenoptera Research 32: 17-44.

Johannessen, E.P.; Steel, R.J. 2005. Shelf-margin clinoforms and prediction of deepwater sands. Basin Research 17: 521-550.

Johnson, K.S.; Paull, C.K.; Barry, J.P.; Chávez, F.P. 2001. A decadal record of underflows from a coastal river into the deep sea. Geology 29: 1019-1022.

Kineke, G.C.; Woolfe, K.J.; Kuehl, S.A.; Milliman, J.; Dellapenna, T.M.; Purdon, R.G. 2000. Sediment export from the Sepik River, Papua New Guinea: evidence for a divergent sediment plume. Continental Shelf Research 20: 2239-2266.

Lamb, M.P.; Mohrig, D. 2009. Do hyperpycnal-flow deposits record river-flood dynamics? Geology 37: 1067-1070.

Lavenu, A.; Encinas, A. 2005. Deformación frágil de los depósitos neógenos de la cuenca de Navidad (Cordillera de la Costa, $34^{\circ} \mathrm{S}$, Chile central). Andean Geology 32 (2): 229-248.

Le Roux, J.P. 2005. Grains in motion: A review. Sedimentary Geology 178: 285-313.

Le Roux, J.P.; Elgueta, S. 2000. Sedimentologic development of a Late Oligocene-Miocene forearc embayment, Valdivia Basin Complex, southern Chile. Sedimentary Geology 130: 27-44.

Le Roux, J.P.; Gómez, C.; Fenner, J.; Middleton, H. 2004. Sedimentological processes in a scarp-controlled rocky shoreline to upper continental slope environment, as revealed by unusual sedimentary features in the Neogene Coquimbo Formation, north-central Chile. Sedimentary Geology 165: 67-92.

Le Roux, J.P.; Gómez, C.A.; Olivares, D.M.; Middleton, H. 2005a. Determining the Neogene behavior of the Nazca Plate by geohistory analysis. Geology 33: 165-168.

Le Roux, J.P.; Gómez, C.; Venegas, C.; Fenner, J.; Middleton, H.; Marchant, M.; Buchbinder, B.; Frassinetti, D.; Marquardt, C.; Gregory-Wodzicki, K.M.; Lavenu, A. 2005b. Neogene-Quaternary coastal and offshore sedimentation in north-central Chile: Record of sea level changes and implications for Andean tectonism. Journal of South American Earth Sciences 19: 83-98.

Le Roux, J.P.; Gutiérrez, N.M.; Hinojosa, L.F.; Pedroza, V.; Becerra, J. 2013. Reply to Comment of Finger et al. (2013) on: 'Evidence for an Early-Middle Miocene age of the Navidad Formation (central Chile): Paleontological, paleoclimatic and tectonic implications' of Gutiérrez et al. (2013, Andean Geology 40 (1): 66-78).
Andean Geology 40 (3): 580-588. doi: 10.5027/ andgeoV40n3-a11.

Le Roux, J.P.; Nielsen, S.N.; Kemnitz, H.; Henríquez, A. 2008. A Pliocene mega-tsunami deposit and associated features in the Ranquil Formation, southern Chile. Sedimentary Geology 203: 164-180.

Le Roux, J.P.; Olivares, D.M.; Nielsen, S.N.; Smith, N.D.; Middleton, H.; Fenner, J.; Ishman, S.E. 2006. Bay sedimentation as controlled by regional crustal behavior, local tectonics and eustatic sea-level changes: Coquimbo Formation (Miocene-Pliocene), Bay of Tongoy, central Chile. Sedimentary Geology 184: 133-153.

Le Roux, J.P.; Vargas, G. 2005. Hydraulic behavior of tsunami backflows: Insights from their modern and ancient deposits. Environmental Geology 49: 65-75.

Middleton, G.V.; Southard, J.B. 1984. Mechanics of Sediment Movement. Second Edition. Lecture Notes for Short Course 3, Rhode Island: $400 \mathrm{p}$.

Mulder, T.; Migeon, S.; Savoye, B.; Jouanneau, J.M. 2001. Twentieth century floods recorded in the deep Mediterranean sediments. Geology 29: 1011-1014.

Mulder, T.; Syvitski, J.P.M. 1995. Turbidity currents generated at river mouths during exceptional discharges to the world oceans. Journal of Geology 103: 285-299.

Mulder, T.; Syvitski, J.P.M.; Migeon, S.; Faugeres, J.C.; Savoye, B. 2003. Marine hyperpycnal flows: initiation, behavior and related deposits. A review: Marine and Petroleum Geology 20: 861-882.

Muñoz, J.; Troncoso, R.; Duhart, P.; Crignola, P.; Farmer, L.; Stern, C.R. 2000. The relation of the mid-Tertiary coastal magmatic belt in south-central Chile to the Late Oligocene increase in plate convergence rate. Revista Geológica de Chile 27 (2): 177-203.

Nichols, G. 1999. Sedimentology and Stratigraphy. Blackwell Science: 355 p. Victoria.

Nielsen, S.N.; Frassinetti, D.; Bandel, K. 2004. Miocene Vetigastropoda and Neritimorpha (Mollusca, Gastropoda) of central Chile. Journal of South American Earth Sciences 17: 73-88.

Paris, R.; Fournier, J.; Poizot, E.; Etienne, S.; Morin, J.; Lavigne, F.; Wassmer, P. 2010. Boulder and fine sediment transport and deposition by the 2004 tsunami in Lhok Nga (western Banda Aceh, Sumatra, Indonesia): A coupled offshore-onshore model. Marine Geology 268: 43-54.

Poschmann, M.; Braddy, S.J. 2010. Eurypterid trackways from Early Devonian tidal facies of Alken an der Mosel (Rheinisches Schiefergebirge, Germany). Palaeobiodiversity and Palaeoenvironments 90: 111-124. 
Price, N.J.; Audley-Charles, M.G. 1987. Tectonic collision processes after plate rupture. Tectonophysics 140: 121-129.

Pszonka, J.; Wendorff, M.; Jucha, K.; Bartynowska, K.; Urbanik, A. 2013. X-ray radiography as a method of detailing the analysis of sedimentary facies, based on example of the Cergowa sandstones (Flysch Carpathians). Przeglạd lekarski 70 (5): 366-369.

Schmidt, A.R.; Perrichot, V.; Svojtka, M.; Anderson, K.B.; Belete, K.H.; Bussert, R.; Dörfelt, H.; Jancke, S.; Mohr, B.; Mohrmann, E.; Nascimbene, P.C.; Nel, A.; Nel, P.; Ragazzi, E.; Roghi, G.; Saupe, E.E.; Schmidt, K.; Schneider, H.; Selden, P.A.; Vávra, N. 2010. Cretaceous African life captured in amber. Proceedings of the National Academy of Sciences of the United States of America 107: 7329-7334.
Southard, J.B.; Boguchwal, L.A. 1990. Bed configurations in depth-velocity size diagrams. Journal of Sedimentary Petrology 41: 903-915.

Turner, E.C.; Narbonne, G.M.; James, N.P. 2010. Framework composition of early Neoproterozoic calcimicrobial reefs and associated microbialites, MacKenzie Mountains, N.W.T., Canada. In Carbonate Sedimentation and Diagenesis in the Evolving Precambrian World (Grotzinger, J.P.; James, N.P.; editors). Society of Economic Paleontologist and Mineralogist, Special Publication 67: 179 -205.

Zavala, C.; Ponce, J.J.; Arcuri, M.; Drittanti, D.; Freije, H.; Asensio, M. 2006. Ancient lacustrine hyperpycnites: A depositional model from a case study in the Rayoso Formation (Cretaceous) of west-central Argentina. Journal of Sedimentary Research 76: 41-59. 


\section{Appendix 1}

\section{Calculation of hyperpycnal flow velocity over continental shelf}

To estimate the hyperpycnal flow velocity, a derivative of the Darcey-Weisbach equation (Middleton and Southard, 1984) for fluid flow down an inclined plane can be used, where the mean flow velocity is given by $U_{m}=\sqrt{\frac{8 g d S}{C_{d w}}}$

The acceleration due to gravity $g$ is $980 \mathrm{~cm} \mathrm{~s}^{-2}$, the bottom slope $S$ ( $\tan$ of the slope angle $\alpha=0.1^{\circ}$ ) is 0.00175 , and the bottom friction coefficient $C_{d w}$ is 0.023 for flat, sandy surfaces. The friction with the ambient water at the top of the flow is here not taken into account, as this value is unknown. This means that the calculated velocity would be a maximum value.

It is assumed here that the river water has a density $\rho_{r}$ of $0.9982 \mathrm{~g} \mathrm{~cm}^{-3}$, and that the hyperpycnal flow has a thickness $d$ of $1 \mathrm{~m}$, containing suspended grains of quartz density $\left(\rho_{s}=2.65 \mathrm{~g} \mathrm{~cm}^{-3}\right)$. The density of sea water $\rho_{w}$ is assumed to be $1.025 \mathrm{~g} \mathrm{~cm}^{-3}$. The concentration of sediments in hyperpycnal flow is normally around 40 $\mathrm{kg} \mathrm{m}^{-3}$ (Lamb and Mohrig, 2009). The hyperpycnal flow density $\rho_{f}$ is therefore estimated as:

$$
\begin{aligned}
& \rho_{f}=\left(1-\frac{40}{998.2}\right)(0.9982)+\left(\frac{40}{998.2}\right)(2.65)=1.0644 \mathrm{~g} \mathrm{~cm}^{-3} \\
& U_{m}=\sqrt{\frac{8\left[\frac{g\left(\rho_{f}-\rho_{w}\right)}{\rho_{w}}\right] d S}{C_{d w}}}=\sqrt{\frac{8\left[\frac{(980)(1.0644-1.025)}{1.025}\right](100)(0.00175)}{0.023}} \approx 47.88 \mathrm{~cm} \mathrm{~s}^{-1}
\end{aligned}
$$




\section{Appendix 2}

\section{Calculation of bivalve transport by hyperpycnal current}

Equations taken from Le Roux (2005) and authors cited therein.

Density of calcite: $\rho_{c}=2.85 \mathrm{~g} \mathrm{~cm}^{-3}$; density of organism: $\rho_{o}=1.2 \mathrm{~g} \mathrm{~cm}^{-3}$; mean density of bivalve: $\rho_{a} \approx 2.0 \mathrm{~g} \mathrm{~cm}^{-3}$ Density of hyperpycnal flow: $\rho=1.0644 \mathrm{~g} \mathrm{~cm}^{-3}$; dynamic viscosity of hyperpycnal flow: $\mu=0.01 \mathrm{~g} \mathrm{~cm} \mathrm{~s}^{-1}$ Submerged density of bivalve: $\rho_{V}=2.0-1.0644=0.9356 \mathrm{~g} \mathrm{~cm}^{-3}$

Dimensions of bivalve: $3 \times 2.5 \times 0.7 \mathrm{~cm}$; nominal bivalve size: $D_{n}=\sqrt[3]{(3)(2.5)(0.7)}=1.74 \mathrm{~cm}$

Dimensionless bivalve size: $D_{d n}=D_{n} \sqrt[3]{\frac{\rho_{f} g \rho_{\gamma}}{\mu^{2}}}=1.74 \sqrt[3]{\frac{(1.0644)(980)(0.9356)}{(0.01)^{2}}}=371.84$

Dimensionless settling velocity of nominal bivalve:

$U_{d w n}=\sqrt{2.531 D_{d n}+160}=\sqrt{(2.531)(371.84)+160}=33.1832$

Settling velocity of nominal bivalve: $U_{w n}=\frac{U_{d w n}}{\sqrt[3]{\frac{\rho_{f}{ }^{2}}{\mu g \rho_{\gamma}}}}=\frac{33.1832}{\sqrt[3]{\frac{(1.0644)^{2}}{(0.01)(980)(0.9356)}}}=66.62 \mathrm{~cm} \mathrm{~s}^{-1}$

Bivalve is disk-shaped, therefore real settling velocity:

$$
U_{w p}=-U_{w n}\left[0.572\left(1-\frac{D_{s}}{D_{l}}\right)^{1.6}-1\right]=-66.62\left[0.572\left(1-\frac{0.7}{3}\right)^{1.6}-1\right]=41.71 \mathrm{~cm} \mathrm{~s}^{-1}
$$

Dimensionless settling velocity: $U_{w p}=\sqrt[3]{\frac{\rho_{f}^{2}}{\mu g \rho_{\gamma}}}=41.71 \sqrt[3]{\frac{(1.0644)^{2}}{(0.01)(980)(0.9356)}}=20.7749$

Dimensionless critical shear stress:

$\beta_{c}=0.0171 \log _{10} U_{d w p}+0.272=0.0171 \log _{10}(20.7749)+0.0272=0.0497$.

Max. value of $\beta_{c}=0.045$.

Critical shear velocity: $U_{*_{c}}=\sqrt{\frac{\beta_{c} g D_{n} \rho_{\gamma}}{\rho}}=\sqrt{\frac{(0.045)(980)(1.74)(0.9356)}{1.0644}}=8.21 \mathrm{~cm} \mathrm{~s}^{-1}$

Flow velocity $1 \mathrm{~m}$ above bed required to transport bivalve:

$$
U_{y}=U_{*_{c}}\left[2.5 \ln \left(\frac{y}{D_{n}}\right)+8.5\right]=8.21\left[2.5 \ln \left(\frac{100}{1.74}\right)+8.5\right]=152.94 \mathrm{~cm} \mathrm{~s}^{-1}
$$

